\title{
Potential Social Media as a Medium Promoting Home Service for Millenial Era
}

\author{
Nova Deria ${ }^{1}$, Hadi Purnomo ${ }^{2}$ \\ \{nova.deria19@mahasiswa.unikom.ac.id ${ }^{1}$, hadi.purnomo@email.unikom.ac.id²\} \\ Fakultas Ilmu Sosial dan Ilmu Politik, Universitas Komputer Indonesia, Indonesia ${ }^{1}$, Departemen \\ Keuangan dan Perbankan, Universitas Komputer Indonesia, Indonesia².
}

\begin{abstract}
The purpose of this study is to find out how much potential benefits can be obtained from social media for home service entrepreneurs. This research used a descriptive method by explaining the process from advertising to feedback from the services offered. The results of this study are to find out how much influence social media as a medium of promotion for Home Service Services in the Millennium Era as it is today and to know all the benefits that have been obtained from social media. This research was conducted by discussing how the power of social media as a media campaign and advertising that used by the Entrepreneurs for their products so that messages and goals can be conveyed well to consumers and can attract consumers to use their services.
\end{abstract}

Keywords: Social Media, Millenial Era, Promoting.

\section{Introduction}

Philip Kotler and Kevin Keller define social media as a tool for consumers to exchange and provide information like pictures, text, videos, and audio with other people or with other companies and otherwise. [1]. The same thing with Ellitan who argues that shopping or buying something in cyberspace that we known more with online shopping is a process where we as buyers or who need services to buy products and services that we need or want on the internet [2]. Likewise, Abdul Muhammad, chief of digital officer, partner at rbb Communications said that cyberspace has the ability to target to reach and scale, at a lower cost if we compared to almost all other marketing channels. Society also on social media in this era is all the time, every day [3].

According to Balea's statement, social media is used by all people in this millennial era as it is now to carry out various activities ranging from entertaining themselves, filling their free time, seeking profits from doing business in any chance, or finding the information they need with very easily [4]. In his book, Swastha argues about the prices, that if the prices set by the service providers suit and match with the purchasing power of consumers, then the selection of goods and services by consumers will be fell to their product [5]. The research had done by We Are Social states mention that in 2016 of the world's 7,395 billion population around 2,307 billion people were active on social media. In Southeast Asia, a total of 234 million users or as much as 30 percent of the total population active on the internet, it is very beneficial for people who want to promote their services because the number of users is very fantastic on social media [6]. With this statement the entrepreneurs are the people who must be more creative in marketing their products to attract consumer interest, this is the same thought accordance with the opinion 
of Lefa and Laroche which states that interest can determine consumer valuation in choosing products and services that are packaged in advertising promotions that provide information on social media [7].

Entrepreneurs must be able to find opportunities in the business world because they can help improve the welfare of the community. The community can be helped by employment opportunities [8].

Madahi and Sukati also mentioned that if consumers' buying interest will arise if they need something after evaluating, and here we can provide it by displaying testimonials so that consumers can give their opinion about our product or service whether it deserves to use or not. [9]. As we know and mentioned by Moayan, social media is a technology network that allows us to spread the news or information on the internet and communicate with consumers. Marketing in cyberspace is a marketing model carried out on the internet service to achieve the marketing objectives of our products by directly engaging in social media itself so that we can directly feel the benefits of social media [10].

The study is to find out how much potential benefits can be obtained from social media for home service entrepreneurs Therefore the process from advertising until the feedback from the service offered uses descriptive method.

\section{Methods}

This study uses descriptive methods to find out what factors in advertising on social media and to find out the influence of social media as a promotional media for Home Services and to use previous research related to the promotion of goods using Social Media. So that we can analyze how much influence of social media that we use and has become a medium of promoting Home Service.

\section{Results And Discussion}

New media is a name given to social media because this media is different from previous media such as magazines, television, and radio. The media as described above are classified as old media which are now slowly being replaced with new media that get a place in the hearts of the people because they can include all of them.

Social media is an effective business promotion tool because it can be accessed by anyone, everyone, and everywhere, so the promotion network can be broader all over the world and anytime. Social media is an indispensable part of marketing for many companies and is one of the best ways to reach a wide range of markets and customers. Social media such as Web, Facebook, Twitter, Instagram, and YouTube have so many benefits for businesses compared by using other conventional media as a promotional medium.

This phenomenon has good potential for the promotion of Home Cleaning Service, especially for homemakers and carrier women.

Indeed, there are so many housemaid services now, but there are also many things offered by Home Cleaning Service that needed by mothers to anticipate the perfection of their clean home and beyond the ability of the housemaids. This is where the role of social media helps service bidders. (see figure 1). 


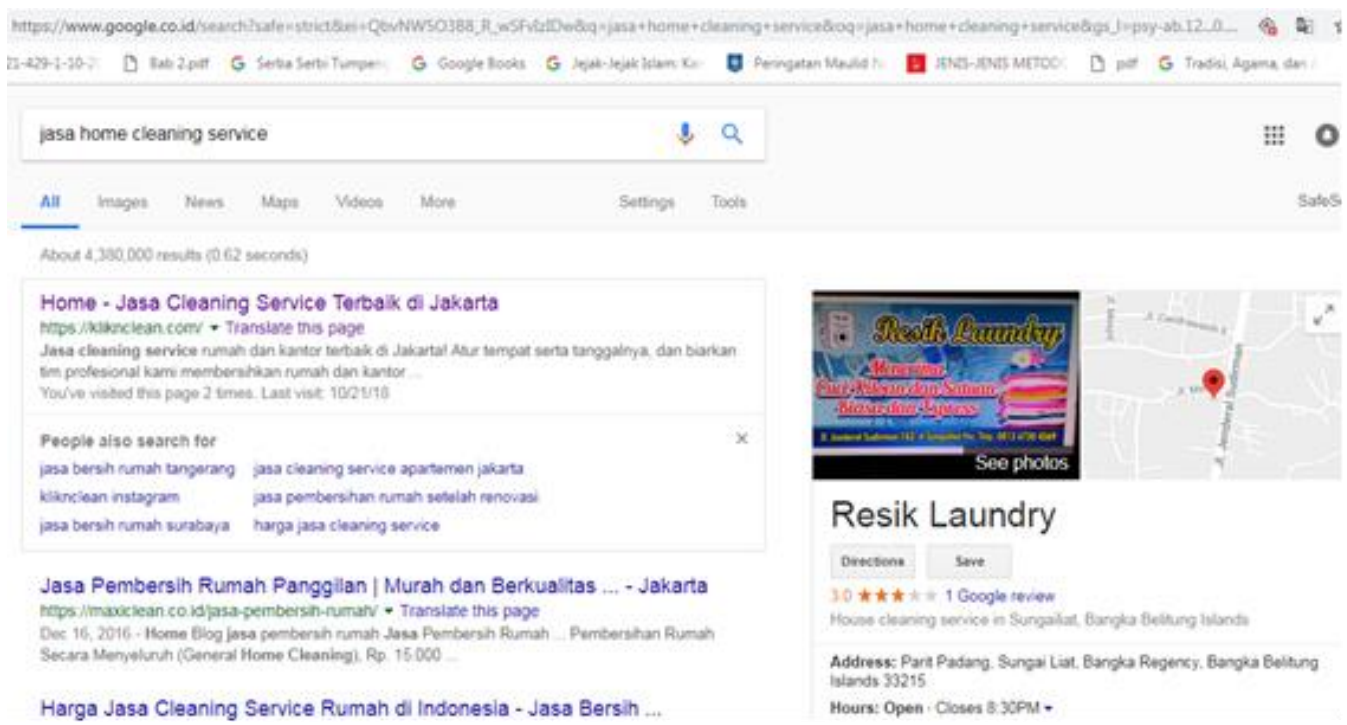

Fig 1. Search result on the internet

Communities in the millennial era, as now, their lives are not spared from the internet. Whatever is needed, the first thing they will do is look for it on the internet.

By using social media, the process of promoting Home Cleaning service can be simpler than on television and radio at a low price.

We can advertise our services anywhere and anytime very simply only by using media social as a medium and smartphone to access. Consumers can also easily to find service bidders on social media because they serve so much information all over the world. (see figure 2 ).

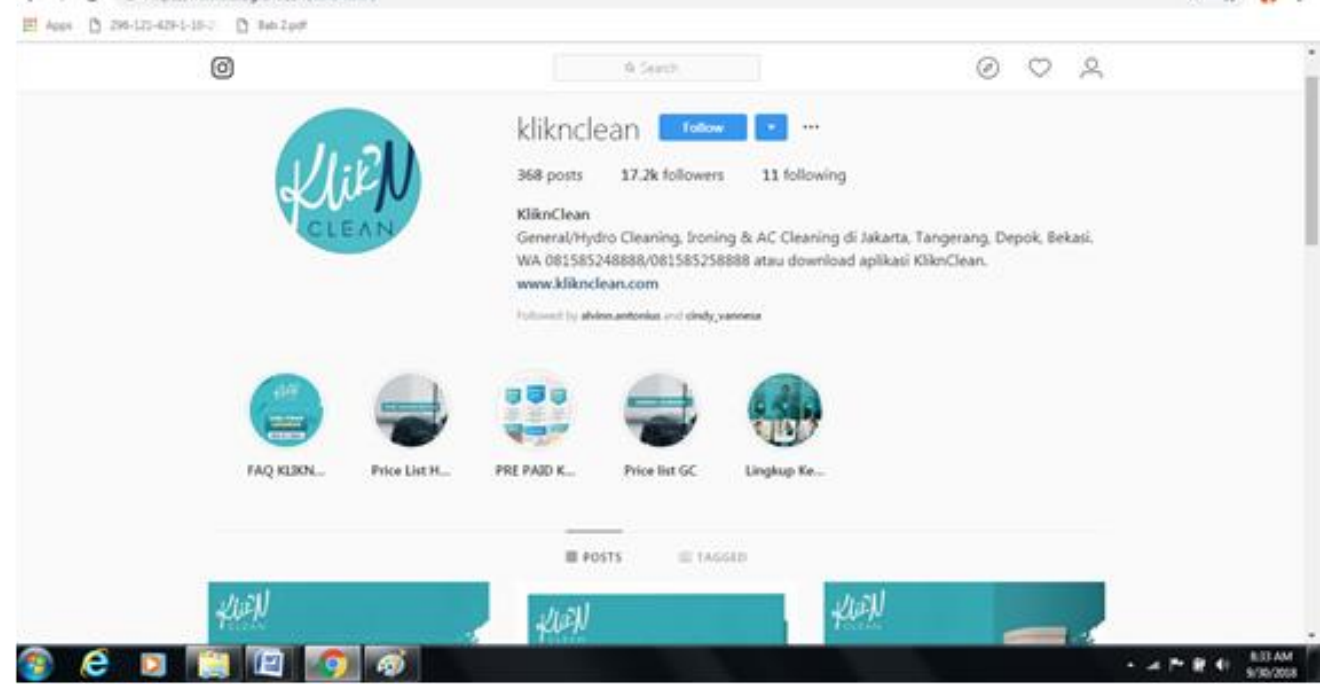

Fig 2. Instagram as Medium of Promotion

To attract consumers' attention and interest in the services that have offered at the time of promotion, sellers must pay attention to the context of the advertisements. Then it will be distributed, by forming a story, benefit and any other good things about Home Cleaning Service 
through the use of language and message content so that it can be covered with nicely for consumers in this Millennial Era.

As well, in conducting and introducing the service promotion, it must also be interesting, such as providing attractive packages price for consumers so consumers feel more save money and can even create loyal customers (see figure 3 ).

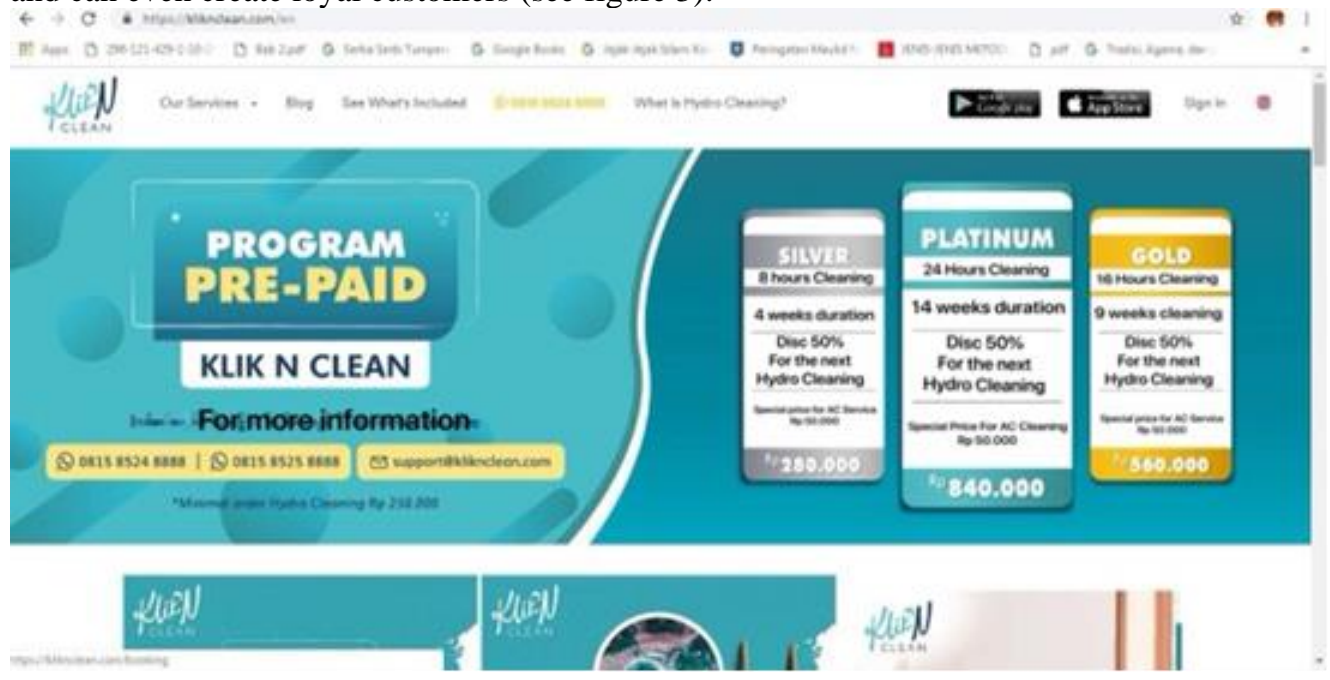

Fig 3. The Packages of the price

When advertisements are distributed on social media, consumers will see what services are offered in Home Cleaning Service. The consumers can choose what parts needed. (see figure 4).

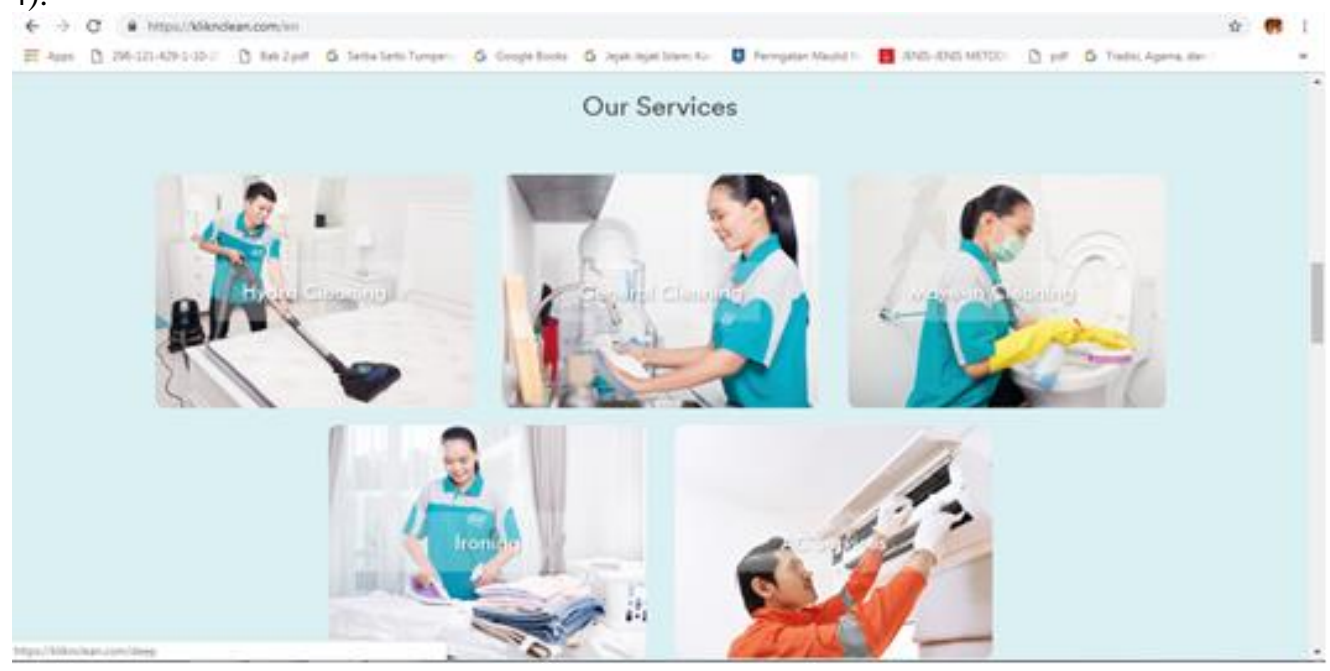

Fig 4. Our Services

However, with all the easy part of advertising on social media, of course, they are many other service bidders do promotional activities too. In this advertising we have to show the superiority of the services that we have. Then turning to how to share stories in the promotional adverts about all the benefits of using Home Cleaning Service in order to make consumers hear, 
respond, and grow so that people become comfortable and all the message is delivered to the intended purpose that we want. (see figure 5).

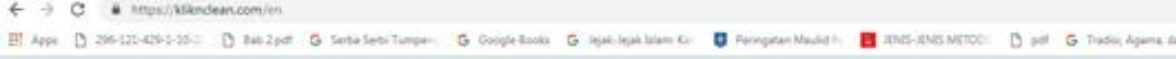

Why KliknClean?
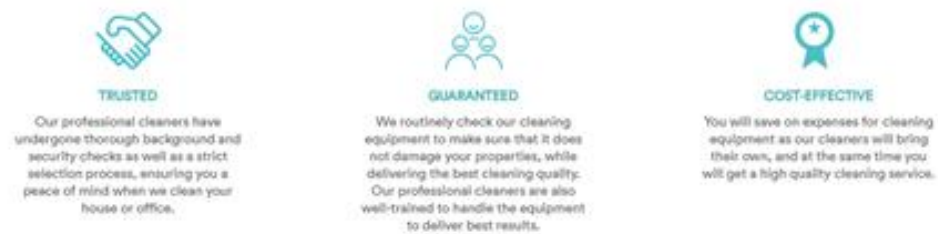

so deliver best ramenth.

num CareFAST

Fig 5. The Benefit

Then social media allows bidders for Home Cleaning Service to communicate quickly with consumers so that if we get negative feedback in service, Home Cleaning Service Services can fix it quickly so that the company's image is maintained and it can also benefit the Company and Consumers. Testimony is also very necessary to strengthen the quality of service services. (see figure 6).

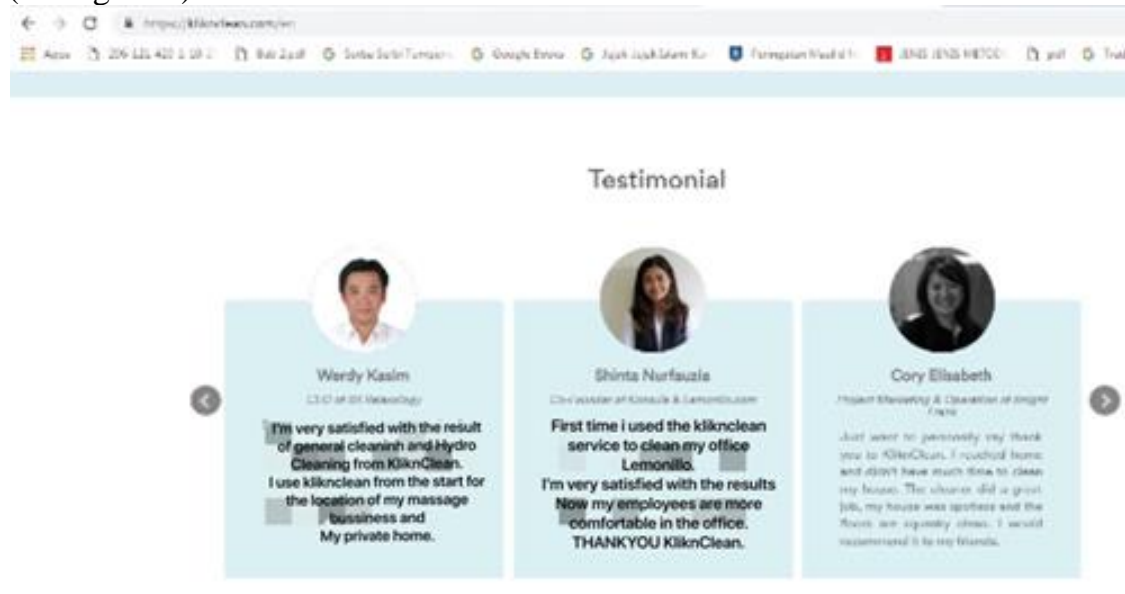

Fig 6. Testimony of the consumers

Within a minute, information about Home Cleaning Service services can be widely spread. Promotions using social media can be clearly controlled and nicely maintained, Home Cleaning Service can get the measured data in an instant about its reach and effectiveness.

Furthermore, the parties must cooperate, in the sense of an account or company that offers Home Cleaning Service services with social media users who aim to make things better, more efficient, 
and more effective as they can submit testimonials, complaints, suggestions after using their services. The last in marketing communications that are packaged in this promotional advertisement is how to maintain and continue to develop the relationships that have been established.

\section{Conclusion}

Social media has a more effective, efficient and inexpensive role when compared to other conventional media. Social media is used as a promotional tool that is very commonly used in the current era and is very profitable for the company, because in the process as easily as that it made our work easier. Especially in the millennial era as it is today, the benefits can be very large. We such as millennial children should be more creative and use social media wisely as a media campaign for businesses. If we focus and work hard and also creative, the results will be seen.

\section{References}

[1] Kotler, Philip dan Armstrong, Gary. PrinsipPrinsip Pemasaran. Jilid 2. Jakarta Erlangga. (2001)

[2] Ellitan, Lena. Supply Chain Management. Cetakan Pertama. Bandung: Penerbit Alfabeta. (2008)

[3] https://www.businessnewsdaily.com/7832-social-media-for-business.html (2017)

[4] Bill Bowers ; Social Media for Business: A Marketer's Guide By Saige Driver, Social Media Strategist April 10, (2018).

[5] Balea, Judith. The Latest Stats In Web And Mobile In Indonesia (Infographic). https:// www.techinasia.com. Accessed 5 Oktober 2018 from https://www.techinasia. com/indonesia-webmobile-statistics-we-are-social. (2016)

[6] Swastha, Basu. Manajemen Pemasaran Modern. Yogyakarta: Liberty. (2002)

[7] https://wearesocial.com/sg/special-reports/digital- (2016)

[8] Setiawan, Edhie Budi. "Quality and Purchase Intention Perceived Value towards Low-Cost Energy-

Saving Cars”. Jurnal Manajemen Transportasi \& Logistik. Vol. 02 No.01, p.107-118. (2015)

[9] Soegoto, D.I. Menjadi pembisnis ulung. Jakarta: PT Elex Media Komputindo (2015)

[10] Madahi, Abdolrazagh dan Inda Sukati. "The Effect of External Factors on Purchase Intention Amongst Young Generation in Malaysia”. International Business Research. Vol. 5 No.8, p. 153-159. (2012)

[11] Maoyan et al. "Consumer Purchase Intention Research Based on Social Media Marketing". International Journal of Business and Social Science. Vol. 5 No.10 (1), p.92-97. (2014) 